\title{
線維性骨異形成症に対する遊離管状自家腓骨移植術の治療経験
}

\author{
国立病院九州医療センター整形外科, 臨床研究部 \\ 前 田剛 - 篠 原典夫 \\ 横 山庫一郎·末 永 英 慈 \\ 佐 藤 陽 昨
}

\section{Clinical Results of Free Auto-fibular Grafts in Fibrous Dysplasia}

\author{
Go Maeda, Norio Shinohara, Koichiro Yokoyama, \\ Eiji Suenaga and Yosaku Satoh \\ Department of Orthopaedic Surgery, \\ Clinical Research Institute, \\ National Kyushu Medical Center Hospital, \\ Fukuoka, Japan
}

\begin{abstract}
We report 13 cases of fibrous dysplasia treated by free auto-fibular grafts from 1990 to 1997 . Their mean age was 16 years (ranging from 6 to 38 years). The mean followup period was 2 years and 10 months. The grafts of free auto-fibular cortical bone were used. The objectives of relief of pain and prevention of deformity were achieved in all 13 patients. 1 patient required an arthrodesis of the hip due to aseptic necrosis. None of the patients had important deformity and no one complained after the resection of the fibula.
\end{abstract}

Key words : Fibrous dysplasia（線維性骨異形成症), Treatment（治療), Fibular graft（腓 骨移植)

は じめに

良性骨腫瘍及び骨腫瘍類似疾患の手術における主な 目的は，支持性を高め病的骨折を防ぐことであり，従 来より一般的治療法として病巣掻爬・骨移植が行われ てきた。 なかでも線維性骨異形成症はしばしば治療が 困難で, 手術後も再発しやすく, 変形により病的骨折 を繰り返すことがある．移植骨には腸骨もしくは銀行 骨が用いられることが多いが, 術後に移植骨の吸収が しばしば見られ，複数回の手術を余儀なくされる. Enneking らは同種の疾患に対し, 移植骨の吸収を防 ぐために, 自家腓骨を管状のまま, 正常組織より正常 組織へ, 病変部を橋渡するように移植すると良いと述 べている ${ }^{3 / 4)}$. 我々は線維性骨異形成症に対しなるべく 手術を避ける方針で望んでいるが, 骨折や疼痛を認め
る症例や, 比較的高年齢児には手術適応としている. 今回，われわれはこの方法を用いた手術症例の比較的 良好な結果を得たので，その有用性と問題点について 報告する。

\section{対象および方法}

対象は 1990 年 8 月から 1997 年 9 月までに手術を行っ た線維性骨異形成症 13 例であり, 性別は男性 6 例, 女性 7 例であった．手術時年齢は 6 才から 38 才まで, 平均 16 才であった。術後観察期間は 3 カ月より 7 年 まで, 平均 2 年 10 カ月であった. 発生部位は, 脛骨 6 例, 大腿骨頸部 5 例, 上腕骨 1 例, 尺骨 1 例であった。 手術方法は, 可及的に病巣怪爬を行ったのち, 骨膜下 に採取した自家管状腓骨を病変部位を橋渡しするよう に移植した，大腿骨頸部では，初期に股関節前面を露 
出し前面より移植を行っていたが, 後の症例は牽引手 術台を用い透視下に行った。 その際, compression hip screwのdrill を使用して外側より穿孔し可及的 掻爬を行った後, 同部より自家管状腓骨を 1 本ないし 2 本刺入した。内固定は必要に応じてプレートまたは スクリユーを用いた。移植骨の変化は, 経時的にレ線 にて観察を行った。また, 腓骨採取後の再生をレ線に て観察した.

$$
\text { 結果 }
$$

13 例中 8 例は内固定を行わず，腓骨を打ち込んで 移植した。4例にスクリユーを用い，1 例にプレート を用いて固定した。脛骨 6 例中 5 例には初回手術より 腓骨を使用し，1例は複数回手術後の再発に対し腓骨 を使用していた，上腕骨及び尺骨の各 1 症例は, 初回 手術より腓骨を使用していた。大腿骨頸部の 5 例中, 3 例は初回手術より腓骨を使用し，1 例は複数回手術 後の再発に対し腓骨を使用していた。また 1 例は内側 骨折を生じ来院した症例で腓骨を用いて手術を行った が, 術後, 骨頭壊死を生じ最終的に関節固定がなされ

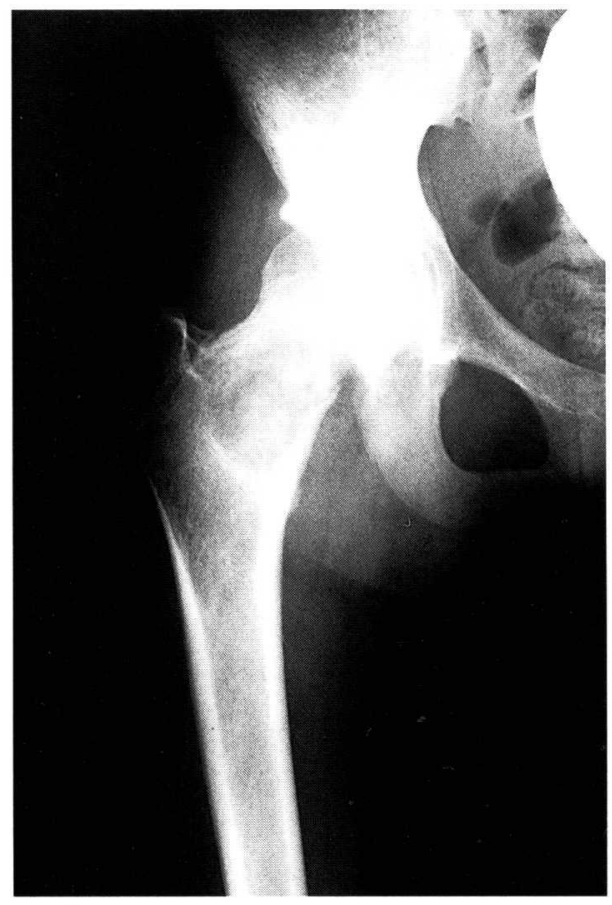

図 1 術前レ線像. 右股頸部に病変を認める.
ていた，移植骨の骨瘉合は全例に認められ，移植骨の 吸収や腫瘍の再発は見られなかった。腓骨採取後の骨 再生は観察しえた 11 例中で検討した結果, 9 例に骨 新生が見られたが, 切除後, 完全に連続性が得られた ものは 20 才以下の症例のみであった。骨シンチが施 行できた例では，移植骨に均一な uptakeを認めた。

症

例

症例, 12 才女性. 右股痛を主訴に来院する。術前, 右大腿骨頸部に病変を認める（図 1)。レ線状，線維 性骨異形成症の診断である，右腓骨を骨膜下に管状の まま採取し，Compression Hip Screw の手技に準 じて可及的病巣掻爬後, 透視下に 2 本頸部に打ち込ん だ.術後 6 カ月で腓骨は完全に癒合する（図 2). 腓 骨の骨皮質は残存し骨吸収を思わせる所見は見られな かった。術後 6 週で荷重を開始し, 疼痛は消失した。 腓骨採取部は, 採取後 6 カ月で完全に再生した。術後 6 カ月での骨シンチでは, 残存病変に強く uptakeを 認めたが, 移植した腓骨部は正常部分と同程度の uptakeだった.

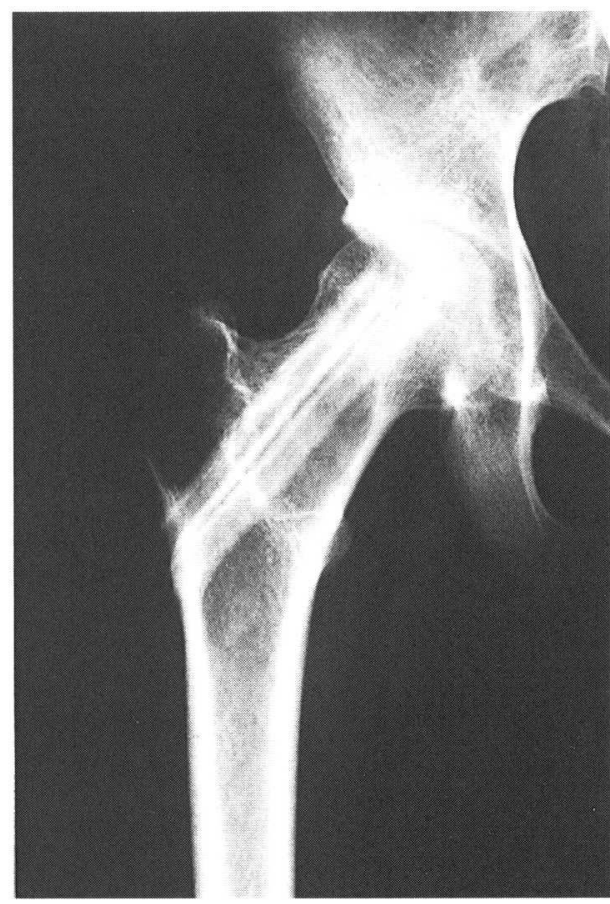

図 2 術後 6 カ月のレ線像. 移植腓骨は完全に 癒合する。 


\section{考察}

大腿骨頸部, 脛骨の線維性骨異形成症は掻爪巴盈移 植では極めて再発しやすく, 偽関節, 変形などかえっ て状態を悪くすることが多いため，手術は極力行わな いようにと言われてきている.しかし，下肢に発生し た場合, 疼痛, 病的骨折, 変形などの問題を生じるた め, 手術的治療により荷重にたえる強固な骨を再建せ ざるを得ない，特に大腿骨頸部では，内反変形が問題 となる．小児ないし若年者が治療の対象になるので, 人工物でなく自己の骨を修復する治療が要求される. 一般的な治療は, 掻爬を行ったのちに骨移植を行うこ とであるが，移植骨に腸骨を用いた場合しばしば吸収 されることがある．また荷重肢においてはその強度に 不安を残す，骨吸収を防ぐための解決方法として血管 柄付き腓骨骨移植があげられる ${ }^{5)}$. 近年, 手技の発達 に伴い手術成績は改善されてきているが, 手術手技が 繁雑で, 長時間を要し, 骨膜とともに腓骨を採取する ので腓骨が再生しない問題を残す。さらには，血管柄 付き腓骨採取後に足部変形や足関節の異常動摇性が報 告されている ${ }^{1 / 2)}$. Enneking は segmental に切除し た骨欠損部への自家腓骨移植を報告しているが3/4, 最 終的に正常の皮質骨と同様の強度が得られると述べて いる，骨膜下に採取した管状腓骨移植の場合，手技が 簡便で, 十分な強度も得られ，また採取後の腓骨再生
も期待できる．今回われわれが手術した症例では全例 骨癒合が得られており，また腓骨の再生は若年者ほど 認められた。以上より自家管状腓骨は荷重肢に対して 良好な移植骨であると考えられた。

$$
\text { ま と め }
$$

(1)線維性骨異形成症 13 例に施行した遊離管状自家 腓骨移植術の治療成績を報告した。

(2)術後に移植骨の吸収や骨折は見られず, 全例に骨 癒合が得られた。

\section{参 考 文 献}

1) Babhulkar, S.S., Pande, K.C., Babhulkar, S.: Ankle instability after fibular resection. J Bone Joint Surg, 77-B : 258-261, 1994.

2) Bohay, D. R., Monoli, A.: Clawtoe deformity following vascularized fibula graft. Foot \& Ankle International, $16: 607-609,1995$.

3) Enneking, W.F. et al.: Autogenous cortical bone grafts in the reconstruction of segmental skeletal defects. J Bone Joint Surg, 62-A : 1039-1058, 1980.

4) Enneking, W.F., Gearen, P. F.: Fibrous dysplasia of the femoral neck. J Bone Joint Surg, 68-A : 1415$1422,1986$.

5) Hsu, R.W.W. et al.: Free vascularised fibular grafting for reconstructionafter tumor resection. $\mathrm{J}$ Bone Joint Surg, 79-B : 36-42, 1996. 